Det erminat i on of $\mathrm{N}$ tric Oxi de by Quenching El ect ro- Chem I um nescence of Tri s( 2, 2- Bi pyri dyl ) rut heni um i n Fl ow I nj ect i on Anal ysi s

\begin{tabular}{|l|l|}
\hline 著者 & $\begin{array}{l}\text { CHEN Ji ngyuan, M YAKE Nasaki , CH Yumu, } \\
\text { N SH UM Toyohi ko, AOK Koi chi }\end{array}$ \\
\hline $\begin{array}{l}\text { j our nal or } \\
\text { publ i cat i on t i t l e }\end{array}$ & El ect roanal ysi s \\
\hline vol une & 19 \\
\hline number & $2-3$ \\
\hline page r ange & $181-184$ \\
\hline year & $2007-01$ \\
\hline URL & ht t p: //hdl . handl e. net /10098/1787 \\
\hline
\end{tabular}




\title{
Determination of Nitric Oxide by Quenching Electro-Chemiluminescence of Tris(2,2'-Bipyridyl)ruthenium in Flow Injection Analysis
}

\author{
Jingyuan Chen,* Masaki Miyake, Yuwu Chi, Toyohiko Nishiumi, Koichi Aoki \\ Department of Applied Physics, University of Fukui, 3-9-1 Bunkyo, Fukui, 910-8507 Japan \\ *e-mail: d020111@icpc00.icpc.fukui-u.ac.jp
}

\begin{abstract}
Quenching of the electro-chemiluminescence of the ruthenium complex was applied for detection of NO at the flow injection apparatus equipped with a homemade gas pressure pump with low noise and a flow-through electrogenerated chemiluminescence (ECL) cell. NO quenched the ECL emission of $\mathrm{Ru}(\mathrm{bpy})_{3}{ }^{2+}$ at the potential of the oxidation of $\mathrm{Ru}(\mathrm{bpy})_{3}{ }^{2+}$ efficiently to set the detection limit of $\mathrm{NO}$ at $0.1 \%$ of concentration of $\mathrm{Ru}(\mathrm{bpy})_{3}{ }^{2+}$. The decrease in ECL intensity is linearly dependent on the logarithmic concentration of NO in the range of $5.7 \times 10^{-7} \mathrm{M}$ to $1.8 \times 10^{-5} \mathrm{M}$. Voltammetric and spectrometric analysis showed that $\mathrm{NO}$ was not coordinated to $\mathrm{Ru}(\mathrm{bpy})_{3}{ }^{2+13+}$, but catalyzed the quenching reaction.
\end{abstract}

Keywords: Electro-chemiluminescence, Nitric oxide, Flow injection apparatus, Tris(2,2'-bipyridyl)ruthenium(II), Gas pump

\section{Introduction}

NO is regarded as one of the major atmospheric pollutants, blocking photochemical reaction cycles [1, 2]. However, it plays an important role in physiological regulation [3] for signal transduction and cytotoxicity [4, 5]. Detection of NO is a significant subject in analytical chemistry, and hence several methods of detecting NO have been developed, including chemiluminescence [6,7], electrochemistry [8,9], bioassay $[10,11]$, spectroscopy $[12,13]$, and photoluminescence [14-16]. The first method is based on the luminescence of NO in the presence ozone in gas phase or in the presence luminol and $\mathrm{H}_{2} \mathrm{O}_{2}$ in solution [7]. The latter method has highly sensitive, and has been widely used for atmospheric [6] and biological analysis [3,11,17]. Recently, Evmiridis and co-workers [18] have developed an on-line detection of NO in the biological flow injection analysis (FIA), and have applied successfully it to in-vivo monitoring of blood and brain tissue.

We suggest here an improvement by use of electrochemiluminescence (ECL) of tris(2,2'-bipyridyl)ruthenium $\left(\mathrm{Ru}(\mathrm{bpy})_{3}\right)[19-21]$ instead of the reaction of luminol with $\mathrm{H}_{2} \mathrm{O}_{2}$. We found in the preliminary work that the ECL of $\mathrm{Ru}(\mathrm{bpy})_{3}{ }^{2+}$ was quenched with NO. Quenching of photoluminescence by NO has been already found on NOadsorbed silica-supported molybdenum catalysts in gas phase [14]. It has also been observed at cadmium selenide coated with metalloporphyrins [15] and at porous silicon
[16]. Thus, the quenching has been supported photochemically. This paper aims at analytical application of the quenching of the ECL.

\section{Experimental}

\subsection{Chemicals and Solutions}

Nitric oxide (Nippon Sanso, Japan) was purified by passing through a degassed $10 \% \mathrm{KOH}$ solution to remove traces of $\mathrm{NO}_{2}$. Saturated NO solutions were prepared by bubbling a mixture of argon and $\mathrm{NO}$ gas for 30 min into a deoxygenated solution. The concentration of the $\mathrm{NO}$ was evaluated from Ostawald's coefficient for a given partial pressure [22]. The carrier solution was phosphate buffer (PBS). $\mathrm{Ru}(\mathrm{bpy})_{3} \mathrm{Cl}_{2}$ was added for ECL measurements.

\subsection{Apparatus}

The homemade ECL apparatus consisted of a flow injection unit (the left in Figure 1) and an ECL detection unit (the right in Figure 1). The flow injection unit included a gas pressure pump, two reservoirs for the sample solution and the carrier solution, and a three-way injection valve. The gas pressure pump (in Figure 2) consisted of the pressure nitrogen bottle (A), the gas buffer chamber (B), and the regulator (C) with the water level, $h$, used for flow rate 


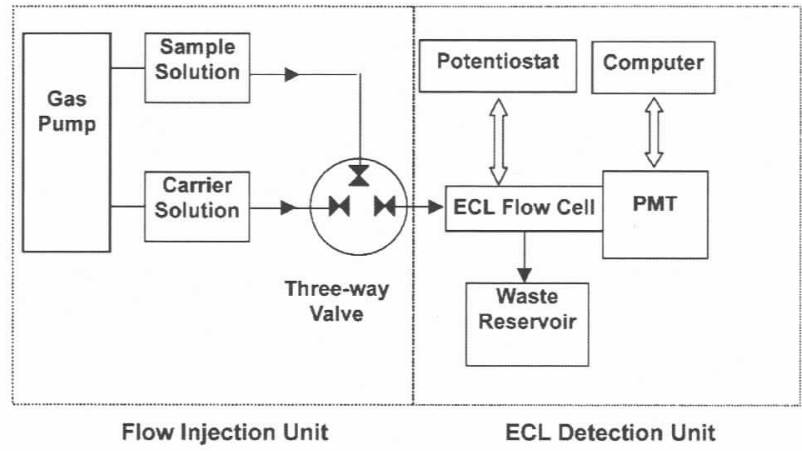

Fig. 1. Illustration of the FI-ECL detection system.

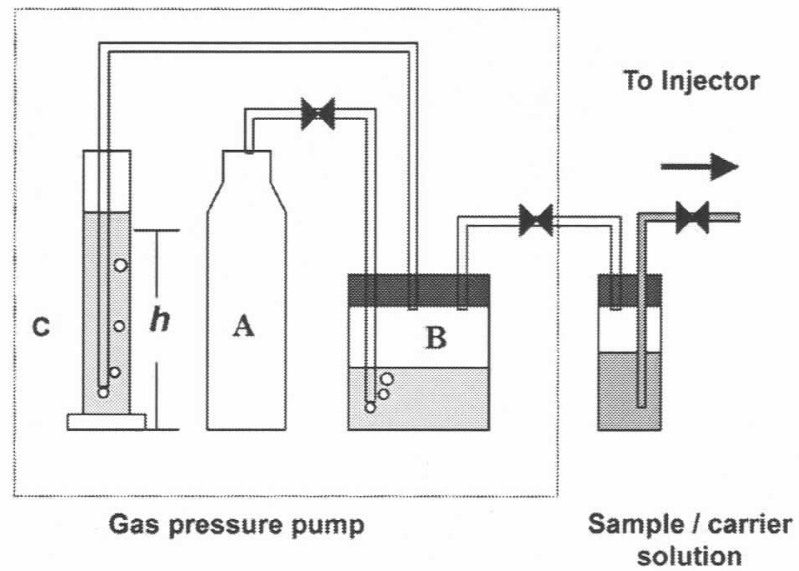

Fig. 2. Illustration of the gas pressure pump. A) A high pressure nitrogen bottle; B) a gas buffer chamber; C) a water reservoir for gas pressure control.

injection control. This pump had $1 \%$ noise of the ECL intensity.

The ECL detection unit consisted of an ECL flow cell, a photomultiplier tube ((PMT) H6780-04, Hamamatsu, Japan), and a potentiostat (1112 Huso, Japan). Current at the PMT was converted into voltage, with a homemade current follower. The voltage was recorded with a computer through an AD-converter. The main body of the ECL cell (Figure 3) was made from a black "T" shaped three-way plastics tube $(3.0 \mathrm{~cm}$ i.d. and $4.0 \mathrm{~cm}$ o.d.). A Pt counter electrode, an $\mathrm{Ag} \mid \mathrm{AgCl}$ reference electrode and a stainless steel pipe serving as the solution outlet were mounted from the top of the cell. At the right side of the cell, a quartz window was mounted in front of the PMT. A Pt wire of $0.1 \mathrm{~mm}$ diameter and $10 \mathrm{~cm}$ long was reeled around the outer wall of the capillary ( $0.5 \mathrm{~mm}$ i.d. and $1.0 \mathrm{~mm}$ o.d.), and was coated with epoxy resin except for the surface near the tip of the capillary. The tip was polished until a flat ring surface was exposed. This glass capillary was inserted into the chamber from the left, to form a thin solution layer between the capillary tip and the quartz window.

A Cray50 (Varian Australia Pty Ltd.) spectrophotometer was used for UV-vis absorption spectra. A NO gas sensor

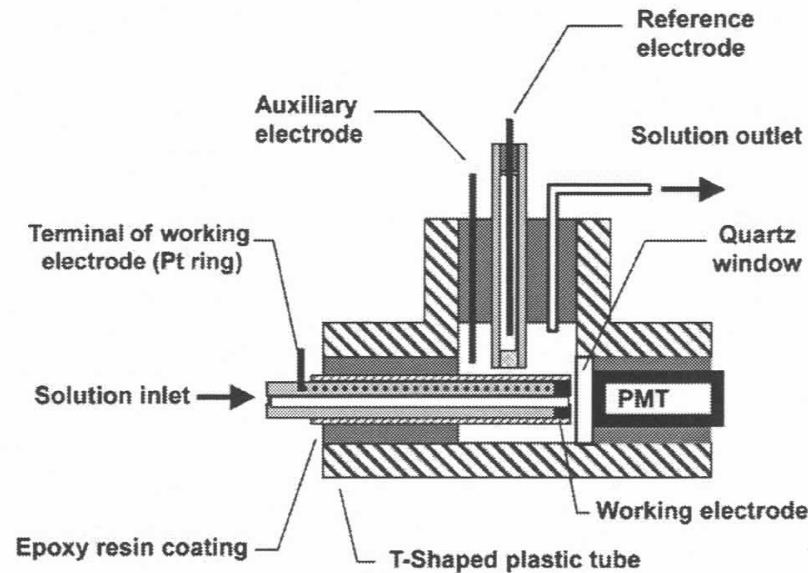

Fig. 3. Structure of the FI-ECL flow-through thin-layer cell.

(Gastec Co., Japan) was used to detect the concentration of $\mathrm{NO}$ in the gas phase above the NO solutions.

\section{Results and Discussion}

\subsection{Preliminary ECL Conditions}

Figure 4 shows the variation of the intensity of ECL emission, $I_{\mathrm{ECL}}$, at the PMT with scanned potential, $E$, for a $\mathrm{Ru}(\text { bpy })_{3}{ }^{2+}$ solution stream in the FI-ECL. The light emission of $\mathrm{Ru}(\mathrm{bpy})_{3}{ }^{2+}$ at the positive potential scan increased at $1.05 \mathrm{~V}$, reached a maximum at $+1.15 \mathrm{~V}$, and then decreased. The ECL emission resulted from reaction of $\mathrm{Ru}(\mathrm{bpy}){ }_{3}{ }^{3+}$ with $\mathrm{OH}^{-}[23]$. On the other hand, the magnitude of ECL peak at the negative scan was smaller than that at the positive scan. This may be caused by depletion of $\mathrm{Ru}(\mathrm{bpy}){ }_{3}{ }^{2+}$ in the diffusion layer. To enhance the detection sensitivity, the potential at the ECL peak, $+1.15 \mathrm{~V}$, was chosen for quantitative analysis.

Dependence of the ECL intensity on the flow rate was investigated in the range of 0 to $5.0 \mathrm{~cm}^{3} \mathrm{~min}^{-1}$. The ECL intensity at a low flow rate $\left(0\right.$ to $\left.0.1 \mathrm{~cm}^{3} \mathrm{~min}^{-1}\right)$ decreased with iterative runs. This is because the diffusion layer is not retrieved with the slow flow. In contrast, a higher flow rate $\left(\geq 0.2 \mathrm{~cm}^{3} \mathrm{~min}^{-1}\right)$ provided reproducible $I_{\mathrm{ECL}}-t$ curve for iterative potential scan. The peak of the ECL intensity, $I_{\mathrm{p}, \mathrm{ECL}}$, increased with an increase in the flow rate, because of the convective supply of $\mathrm{Ru}(\mathrm{bpy})_{3}{ }^{2+}[20]$. It reached a constant value for the flow rate higher than $1.0 \mathrm{~cm}^{3} \mathrm{~min}^{-1}$. This implies that $I_{\mathrm{p}, \mathrm{ECL}}$ is controlled by the slow ECL kinetics [21]. The intensity increased with an increase in the scan rate over the range of $5 \mathrm{mV} \mathrm{s}^{-1}$ to $75 \mathrm{mV} \mathrm{s}^{-1}$, and reached a constant value at the higher scan rates. This pattern can be explained in terms of the competition between the convective diffusion and the ECL kinetics. Therefore scan rate of $100 \mathrm{mV} \mathrm{s}^{-1}$ was selected for subsequent experiments.

$I_{\text {p.ECL }}$ increased with an increase in the concentration of $\mathrm{Ru}(\mathrm{bpy})_{3}{ }^{2+}$ over the range of $1.0 \times 10^{-6} \mathrm{M}$ to $5.0 \times 10^{-4} \mathrm{M}$. It 


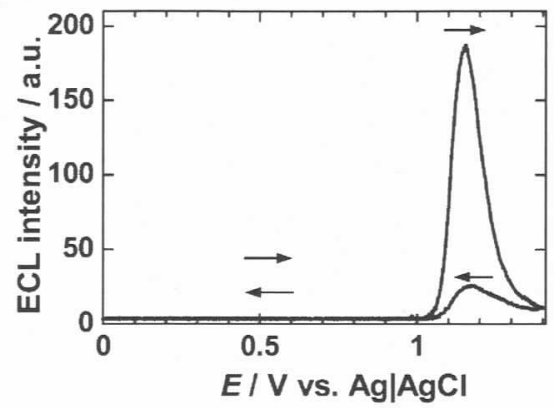

Fig. 4. Cyclic $I_{\mathrm{ECL}}-E$ curve obtained in the $5.0 \times 10^{-4} \mathrm{M}$ $\mathrm{Ru}(\mathrm{bpy})_{3}{ }^{2+}+\mathrm{pH} 12.0$ PBS solution at the flow rate of $1.0 \mathrm{~cm}^{3}$ $\mathrm{min}^{-1}$ for the potential scan rate of $100 \mathrm{mV} \mathrm{s}^{-1}$.

reached the maximum at $5.0 \times 10^{-4} \mathrm{M}$. Therefore this concentration was selected for the ECL detection of NO.

\subsection{Inhibition of ECL by NO}

The $I_{\mathrm{ECL}}$ vs. $E$ curves of $\mathrm{Ru}(\mathrm{bpy})_{3}{ }^{2+}$ in the absence and in the presence of NO are shown in Figure 5. The intensity decreased with the increase in the concentration of NO. The quenching of the ECL was not only reproducible but also sensitive to $\mathrm{NO}$, and hence the amount of the quenching can be used for quantitative determination of NO. We use $\Delta I_{\mathrm{ECL}}=I_{[\mathrm{NO}]=0}-I_{[\mathrm{NO}]}$ as a measure of relating concentration of NO. The amount of the quenching increased with an increase in concentration of NO. The inhibited intensity showed a linear relation with the logarithm of the concentration, $c$, of $\mathrm{NO}$

$\Delta I_{\mathrm{ECL}}($ a.u. $)=25.35+(112 \pm 0.17) \log (c(\mu \mathrm{M}))$

This was valid in the range $8.5 \times 10^{-7} \mathrm{M}$ and $1.8 \times 10^{-5} \mathrm{M}$, as is shown in Figure 6. The detection limit of NO, a point extrapolated to $\Delta I_{\mathrm{ECL}}=0$, was $5.7 \times 10^{-7} \mathrm{M}$.

$\mathrm{NO}$ has been reported to be readily coordinated with transition metals [24], especially, with iron porphyrins [2527]. Coordination of $\mathrm{NO}$ with $\mathrm{Ru}(\mathrm{bpy})_{3}{ }^{2+}$ might decrease the concentration of $\mathrm{Ru}(\mathrm{bpy})_{3}{ }^{2+}$ simply to deactivate the ECL. The UV-vis spectra of $\mathrm{Ru}(\mathrm{bpy})_{3}{ }^{2+}$ before and after bubbling NO were overlapped and hence there is no possibility of forming $\mathrm{Ru}(\mathrm{bpy})_{3}$-NO complexes. The voltammogram of $\mathrm{Ru}(\mathrm{bpy})_{3}{ }^{2+}$ had the oxidation peak at $1.11 \mathrm{~V}$ (Figure 7c), whereas that of NO had two oxidation waves at $0.57 \mathrm{~V}$ and $0.77 \mathrm{~V}$ (Figure $7 \mathrm{~b}$ ). When $\mathrm{Ru}(\mathrm{bpy})_{3}{ }^{2+}$ coexisted with $\mathrm{NO}$, its peak potential did not shift at any scan rate (Figure 7d), and its wave was a simple sum of the two waves. Consequently, $\mathrm{NO}$ is not complexed with $\mathrm{Ru}(\mathrm{bpy})_{3}{ }^{2+}$.

An interesting point of the present NO detection lies in the fact that the ECL intensity, which is proportional to the concentration of $\mathrm{Ru}(\mathrm{bpy})_{3}{ }^{2+}$ for less than $0.5 \mathrm{mM}$, was diminished with NO of which concentration was much less than that of $\mathrm{Ru}(\mathrm{bpy})_{3}{ }^{2+}$. These are two possibilities: NO would be adsorbed until its concentration reaches the value

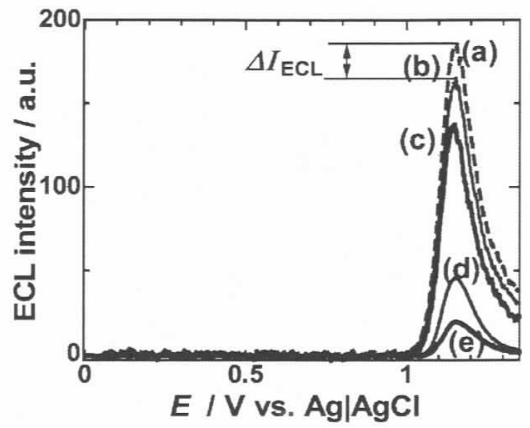

Fig. 5. Cyclic $I_{\mathrm{ECL}}-E$ curve obtained for the flowing Ru(bpy $)_{3}{ }^{2+}$ solution in the presence of various concentrations of $\mathrm{NO}: \mathrm{a}) 0, \mathrm{~b}$ ) $8.5 \times 10^{-7}$, c) $1.8 \times 10^{-6}$, d) $1.0 \times 10^{-5} \mathrm{M}$, and e) $1.8 \times 10^{-5} \mathrm{M}$.

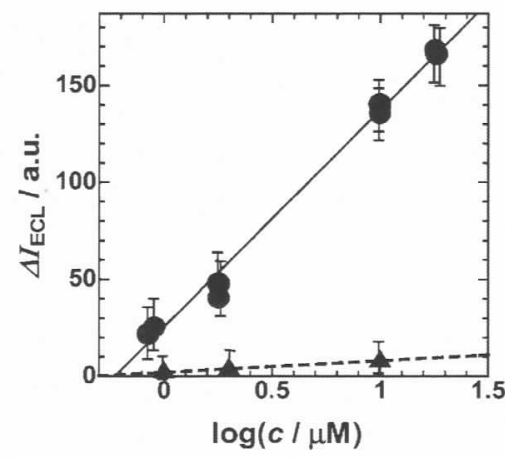

Fig. 6. Dependence of the inhibited ECL intensity on the logarithm of the concentration of $\mathrm{NO}$ (circle) and $\mathrm{NaNO}_{2}$ (triangle).

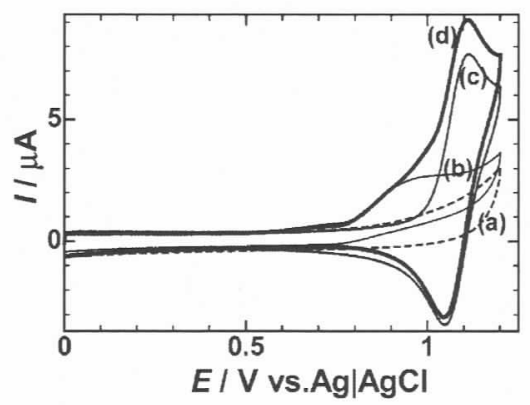

Fig. 7. Cyclic voltammograms of a) $\mathrm{pH} 12.0$ PBS buffer only; b) including $\left.1.8 \times 10^{-5} \mathrm{M} \mathrm{NO}, \mathrm{c}\right)$ including $5.0 \times 10^{-4} \mathrm{M} \mathrm{Ru}(\mathrm{bpy})_{3}{ }^{2+}$ and d) mixed solution of (b) and (c) at the platinum ring electrode (300- $\mu \mathrm{m}$ diameter) for the scan rate of $0.1 \mathrm{~V} \mathrm{~s}^{-1}$.

of concentration of $\mathrm{Ru}(\mathrm{bpy})_{3}{ }^{2+}$ or $\mathrm{NO}$ would work catalytically to block the ECL. Voltammetry of NO did not show any proof of adsorption NO. The catalytic effect is conceivable in that $\mathrm{NO}$ consumes catalytically $\mathrm{HO}_{2} \cdot[28,29]$ which plays a main role in the ECL [23].

The significant interference may be caused by $\mathrm{NO}_{2}^{-}$, which is generated by the reaction of NO with water [30]. $\mathrm{NaNO}_{2}$ also quenched the ECL emission under the same 
conditions as NO. However, the quenching was $5 \%$ of that NO, as show in Figure 6.

\section{Conclusions}

The FI-ECL apparatus allowed us to determine NO with reproducibility and high sensitivity. The inhibited ECL intensity $\left(\Delta I_{\mathrm{ECL}}\right)$ was increased linearly with the logarithm of $\mathrm{NO}$ concentration in the range of $5.7 \times 10^{-7} \mathrm{M}$ to $1.8 \times$ $10^{-5} \mathrm{M}$. The characteristic of this detection lies in such high sensitivity of the quenching that we cannot predict from the ECL intensity of only $\mathrm{Ru}(\mathrm{bpy})_{3}{ }^{2+}$. Therefore the quenching is ascribed to a catalytic reaction. The high performance of the detection has been supported by using the gas pressure pump of low flow pulse and the flowthrough ECL cell. The pump was useful for removing the significant flow pulse at a peristaltic pump.

\section{Acknowledgement}

This work was financially supported by Grants-in-Aid for Scientific Research (Grants 18350041) from the Ministry of Education in Japan.

\section{References}

[1] J. M. Robert, Atmos. Environ. 1990, 24A, 243.

[2] G. Moréac, P. Dagaut, J. F. Roesler, M. Cathonnet, Combustion and Flame 2006, 145, 512.

[3] R. M. J. Palmer, A. G. Ferrige, S. Moncada, Nature 1987, 327, 524.

[4] M. A. Marletta, M. A. Tayeh, J. M. Hevel, Biofactors 1990, 2, 219.
[5] D. E. Koshland, Science 1992, 258, 1861.

[6] M. J. Navas, A. M. Jimenez, G. Galan, Atmos. Environ. 1997 31,3603 .

[7] K. Kikuchi, T. Nagano, H. Hayakawa, Y. Hirata, M. Hirobe, Anal. Chem. 1993, 65, 1794.

[8] F. Bedioui, N. Villeneuve, Electroanalysis 2003, 15, 5.

[9] J. Chen, O. Ikeda, Electroanalysis 2001, 13, 1076.

[10] F. Shintani, S. Kanba, T. Nakaki, K. Sato, G. Yagi, R. Kato, M. Asai, J. Psychiatry Neurosci. 1994, 19, 217.

[11] P. R. Myers, R. Guerra, D. G. Harrison, Am. J. Physiol. 1989, 256, H1030,

[12] M. Kelm, R. Dahamann, D. Wink, M. Feelisch, J. Biol. Chem. 1997, 272, 9922 .

[13] P. Mordvintcev, A. Mulsch, R. Busse, A. Vanin, Anal. Biochem. 1991, 199, 142.

[14] B. Shelimov, V. Dellarcca, G. Martra, S. Coluccia, M. Che, Catal. Lett. 2003, 87, 73.

[15] A. Ivanisevic, M. F. Reynolds, J. N. Burstyn, A. B. Ellis, J. Am. Chem. Soc. 2000, 122, 3731.

[16] J. Harper, M. J. Sailor, Anal. Chem. 1996, 68, 3713.

[17] R. M. J. Palmer, D. S. Ashton, S. Moncada, Nature 1988, 333, 664.

[18] N. P. Evmiridis, D. Yao, Anal. Chim. Acta 2000, 410, 167.

[19] M. M. Richter, Chem. Rev. 2004, 104, 3003.

[20] X. B. Yin, S. J. Dong, E. Wang, Trends Anal. Chem. 2004, 23, 432.

[21] D. Ege, W. G. Becker, A. J. Bard, Anal. Chem. 1984, 56, 2413.

[22] D. R. Lide, CRC Handbook of Chemistry Physics, 76th ed., CRC Press, Boca Raton, FL 1995, sect. 6-3.

[23] J. E. Martin, E. J. Hart, A. W. Adamson, H. Gafney, J. Halpern, J. Am. Chem. Soc. 1972, 94, 9238.

[24] J. A. McCleverty, Chem. Rev. 2004, 104, 403.

[25] J. Chen, O. Ikeda, T. Hatasa, A. Kitajima, M. Miyake, A. Yamatodani, Electrochem. Commun. 1999, 1/7, 274.

[26] G. R. A. Wyllie, W. R. Scheidt, Chem. Rev. 2002, 102, 1067.

[27] Y. Chi, J. Chen, K. Aoki, Inorg. Chem. 2004, 43, 8437.

[28] P. Dagaut, G. Dayma, J. Phys. Chem. A, 2006, 110, 6608

[29] C. J. Howard, J. Am. Chem. Soc. 1980, 102, 6937.

[30] S. V. Lymar, V. Shafirovich, G. A. Poskrebyshev, Inorg. Chem. 2005, 44, 5212. 